\title{
Media sosial sebagai model tradisi bertandang baru di era digital
}

\author{
Andika Andika *, Mulia Jaya \\ Program Studi Ilmu Pemerintahan, Fakultas Ilmu Sosial dan Ilmu Politik, Universitas Muara Bungo \\ * Corresponding Author. E-Mail: andikaumb@gmail.com
}

\begin{abstract}
Info Artikel
Abstrak

Histori Artikel:
Received: 9 Dec. 2019

Revision: 18 Dec. 2019

Accepted: 31 Dec. 2019

Kata Kunci: media sosial; era digital; tradisi bertandang; social media; away tradition; digital era

Tujuan dilakukan penelitian ini adalah untuk mengetahui penggunaan facebook sebagai model tradisi bertandang baru di era digital di Desa Tunggul Bulin Kecamatan Tabir Ilir Kabupaten Merangin dan untuk mengidentifikasi apa faktor yang mempengaruhi penggunaan facebook sebagai model tradisi bertandang di era digital. Metode yang digunakan dalam penelitian ini penelitian ini adalah metode penelitian kualitatif yang bersifat dengan studi deskriptif. Metode yang digunakan dalam penelitian ini penelitian ini adalah metode penelitian kualitatif yang bersifat dengan studi deskriptif. Teknik pemilihan informan yang digunakan oleh peneliti dalam penelitian ini adalah dengan menggunakan metode purposive sampling (teknik penentuan sampel dengan pertimbangan tertentu). Hasil penelitian ini menunjukkan bahwa Tradisi bertandang lambat laun memudar dan menghilang seiring dengan perkembangan pengetahuan, teknologi, seni, dan budaya di tengah masyarakat, pendidikan yang tinggi di tengah masyarakat yang membuat tradisi bertandang tidak lagi dilakukan, mereka sudah berkirim pesan, bertemu di sekolah, di jalan, di pasar, dan di berbagai tempat. Kemudian juga teknologi seperti media, penerang listrik, dan informasi juga membuatkan tradisi bertandang memudar dan menghilang, salah satu penyebab terbesarnya adalah penggunaan media sosial, khususnya facebook. Hal ini dikarenakan penggunaan facebook dalam mencari teman, mengenal dari profil facebook, komunikasi tanpa rasa gugup.
\end{abstract}

The purpose of this research is to find out the use of Facebook as a model of a new visiting tradition in the digital era in Tunggul Bulin Village, Tabir Ilir District, Merangin District and to identify what factors influence the use of Facebook as a model of visiting tradition in the digital era. The method used in this study is a qualitative research method that is descriptive in nature. The method used in this study is a qualitative research method that is descriptive in nature. The informant selection technique used by researchers in this study is to use a purposive sampling method (sampling technique with certain considerations). The results of this study indicate that the tradition of travel gradually fades and disappears along with the development of knowledge, technology, art, and culture in the community, higher education in the community that makes the visiting tradition no longer carried out, they have sent messages, met at school, on the street, in the market, and in various places. Then also technology like media, electricity, and information also makes the tradition of travel fade and disappear, one of the biggest causes is the use of social media, especially Facebook. This is due to the use of Facebook in finding friends, getting to know from your facebook profile, communication without feeling nervous.

This work is licensed under a Creative Commons Attribution-ShareAlike 4.0 International License.

\section{PENDAHULUAN}

Dari berkembangnya teknologi informasi komputer yang pesat ini, peran serta masyarakat sangat besar dari perkembangannya. Hal ini dikarenakan perubahan cepat dalam teknologi informasi telah merubah budaya sebagian besar masyarakat dunia, terutama yang tinggal di perkotaan. Masyarakat diseluruh dunia telah mampu berinteraksi dan memperoleh informasi dalam waktu singkat berkat teknologi komunikasi dan informasi yang mengalami perkembangan yang sangat luar biasa (Hasibuan, 2015).

Pada prinsipnya setiap perkembangan dan kemajuan dalam segi apapun baik adanya, setiap manusia menginginkan perubahan pun dalam konteks kehidupan bermasyarakat. Dari sekian banyak 
Jurnal Politik dan Pemerintah Daerah, 1 (2), 2019 - 96

Andika Andika, Mulia Jaya

bidang ada dan berpacu untuk kemajuan salah satunya adalah bidang teknologi, yang menghadirkan perubahan dan kemajuan untuk selanjutnya digunakan oleh manusia (Hasibuan, 2015). Pengaruh globalisasi membawa penyebaran teknologi, ekonomi, pertukaran politik dan budaya ke penjuru dunia tanpa dibatasi oleh wilayah.

Adanya teknologi baru dapat menciptakan kebudayaan yang baru pada masyarakat serta teknologi sebagai pertanda kemajuan kebudayaan. Semakin berkembangnya teknologi dimana informasi apa saja bisa masuk dalam kehidupan masyarakat kita, berarti ikut serta mempengaruhi tergesernya nilai-nilai budaya Indonesia ini. Banyak masyarakat Indonesia, terutama generasi muda kebanyakan lebih suka terhadap budaya asing ketimbang kebudayaan Indonesia sendiri. Hal ini menuntut kita untuk lebih waspada dalam menerima budaya luar/asing (Hasibuan, 2015).

Perkembangan teknologi tentu membawa perubahan yang begitu baik dan pesat dalam kehidupan manusia. Perkembangan itu baik adanya jika sesuai dengan apa yang diharapkan. Ilmu pengetahuan dan teknologi sangat besar pengaruhnya dalam kehidupan berbudaya. Teknologi sendiri dapat muncul dari ilmu pengetahuan yang selalu berkembang dari zaman ke zaman. Namun, pengaruh ilmu pengetahuan dan teknologi dalam pembentukan budaya mempunyai dampak positif maupun negatif (Hasibuan, 2015).

Media sosial merupakan sarana komunikasi masa kini yang sangat pesat dan cepat dalam perkembangannya (Putri, Nurwati, \& Budiarti, 2016), selain itu sosial media saat ini bisa dikatakan telah menjadi ujung tombak sarana komunikasi khususnya bagi para remaja. Dalam perkembangannya, media sosial mampu menjadi salah satu fasilitas untuk berkomunikasi para remaja. Di era digital ini tentu sangat banyak bermunculan teknologi-teknologi maupun sarana komunikasi yang canggih dan sangat digemari oleh para remaja.

Dari dampak negatif yang ditimbulkan dari perkembangan teknologi informasi ini adalah terciptanya sifat dan sikap ketergantungan kepada teknologi yang semakin canggih sehingga banyak orang yang mulai melupakan nilai-nilai kebudayaan yang ada di Indonesia. Sebagai salah satu contoh, pemuda di Desa Tunggul Bulin Kecamatan Tabir Ilir Kabupaten Merangin telah mulai meninggalkan adat bertandang.

Tradisi bertandang adalah pergaulan bujang gadis (muda-mudi), hal ini dilakukan dengan peraturan yang sudah baku sejak zaman dahulu seperti; bapak dari gadis yang akan ditandangi bujang pada malam itu selesai sholat isya atau habis makan malam menghindar ke rumah tetangga, ibu si gadis sore hari sudah mencari seorang gadis lain untuk teman anak gadisnya, begitu pula bujang yang akan bertandang sore harinya sudah mencari teman sama bujang (Syukur, 1993).

Setelah sholat isya bujang naiklah ke rumah anak gadis yang telah ditentukan dengan mengucapkan salam. Sewaktu mereka bertandang mereka berbalas pantun antara laki dan perempuan, kemudian para bujangan masuk dan keluar kampung dengan bersuling di tangan, mereka piawai bersuling, dan terakhir tape merambah dunia mereka, masing membawa tape sembari mendengar dendang lagu yang dilantun oleh penyanyi ternama dan mereka ikut bernyanyi bersama (Syukur, 1993).

Berdasarkan observasi awal peneliti di Desa Tunggul Bulin Kecamatan Tabir Ilir diketahui bahwa Desa Tunggul Bulin merupakan salah satu desa dalam wilayah Tabir Ilir yang masih mempertahankan adat bertandang, namun perkembangan teknologi informasi telah mulai memberikan dampak nyata terhadap pergeseran sarana perkenalan anak muda di desa tersebut, yang dahulunya masih menggunakan adat bertandang sebagai sarana perkenalan namun sekarang tradisi bertandang sudah mulai ditinggalkan, mereka sudah berkirim pesan melalui media komunikasi handphone (media sosial). Kemudian juga teknologi seperti media sosial, dan informasi juga membuatkan tradisi bertandang memudar dan menghilang.

Salah satu sosial media yang cenderung digunakan adalah facebook. Pesatnya penggunaan facebook, kini menggeser kebudayaan komunikasi tatap muka. Interaksi tatap muka yang semula terjadi setiap hari, tergeser dan seolah-olah luntur dengan semakin berkembangnya media yang digunakan untuk berkomunikasi. Dari mulai surat menyurat, telpon, sms dan kini media sosial.

Media sosial memudahkan manusia untuk berkomunikasi kapan saja dan dimana saja selama ada jaringan internet. Jejaring sosial yang sedang digandrungi oleh masyarakat saat ini adalah Twitter.com dan Facebook.com. Melalui situs tersebut, mereka dapat saling memberi informasi dan dapat menemukan hal yang baru seperti teman atau hal selainnya. 
Jurnal Politik dan Pemerintah Daerah, 1 (2), 2019 - 97

Andika Andika, Mulia Jaya

Penggunaan facebook di Desa Tunggul Bulin semakin meningkat. Semakin meningkatnya pertumbuhan pengguna facebook di Desa Tunggul Bulin tentunya memberikan perubahan-perubahan terhadap pola pergaulan, terutama bertandang. Adat bertandang yang menjadi kebiasaan dan kelaziman berubah ke pola pergaulan modern yaitu adanya kemajuan media yang digunakan, atau cara menyampaikan suatu pesan tanpa harus memerlukan waktu lama dalam penyampainnya.

Selain dari intensitas kunjungan tatap muka langsung yang berkurang, penggunaan facebook sebagai media baru bertandang pada era digital juga memberikan dampak negatif, dimana orang tua pihak perempuan tidak dapat mengontral pergaulan sang anak, bahkan banyak orang tua perempuan tidak mengenali pasangan atau teman lelaki yang dekat dengan perempuan, berbeda sekali ketika adanya pelaksanaan bertandang, dimana pihak laki-laki mengunjungi pihak perempuan yang didampingi oleh ibu dari perempuan. ${ }^{1}$

\section{METODE}

Dalam penelitian ini yang menjadi lokasinya adalah Desa Tunggul Bulin Kecamatan Tabir Ilir Kabupaten Merangin. Alasan memilih lokasi ini dikarenakan peneliti melihat bahwa di Desa Tunggul Bulin merupakan salah satu desa yang masih mempertahankan adat bertandang dalam wilayah serumpun marga Tabir serta melihat perkembangan media sosial saat ini. Penelitian ini dilaksanakan pada bulan Februari sampai dengan April 2018.

Metode yang digunakan dalam penelitian ini adalah metode penelitian kualitatif yang bersifat studi kasus. Jenis penelitian kualitatif dapat diartikan sebagai pendekatan yang meng-hasilkan data, tulisan, tingkah laku yang yang didapat dari apa yang diamati. Berkenaan dengan penelitian ini maka penelitian ini akan menjelaskan dan menggambarkan sesuai dengan data yang didapatkan di lokasi penelitian. Data yang diperlukan dalam penelitian kualitatif bukan data yang berupa angka-angka, melainkan kata-kata yang bersifat kualitatif sehingga metode yang digunakan dalam penelitian itu adalah metode kualitatif. Menurut Bogdan dan Taylor (1992), metode kualitatif adalah prosedur penelitian yang menghasilkan data deskriptif yang berupa kata-kata tertulis atau lisan dari orang-orang dan perilaku yang diamati (Moleong, 2004).

\section{Teknik Pengumpulan Data}

Teknik pengumpulan data yang digunakan dalam penelitian ini adalah observasi, dokumentasi, dan wawancara.

\section{Observasi}

Dalam penelitian ini, peneliti langsung ke lapangan untuk mengamati. Hasil observasi atau pengamatan ini kemudian dituangkan dalam bentuk catatan lapangan. Cara seperti ini dilakukan untuk mengenal secara lebih dekat kondisi dan situasi objek penelitian. Dengan observasi, data yang di kumpulkan cenderung mempunyai keandalan yang tinggi. Hal-hal yang di observasi dalam penelitian ini tentunya tidak terlepas dari beberapa pokok permasalahan yang dibahas berupa mengamati jumlah pengguna facebook, jumlah penggiat bertandang.

Wawancara

Wawancara mendalam yaitu proses tanggung jawab antara peneliti dengan informan secara langsung dengan menggunakan pedoman wawancara. Dalam penelitian ini, peneliti akan melakukam wawancara kepada orang-orang yang menjadi informan dari penelitian ini.

Wawancara terbuka ini terdiri dari pertanyaan-pertanyaan yang menuntut jawaban dari informan yang tidak terbatas dalam jawaban-jawabannya kepada beberapa kata atau hanya pada jawaban "ya" atau "tidak" saja, tetapi dapat memberikan keterangan dan cerita yang panjang.

Dalam wawancara ini terjadi percakapan antara pewawancara dengan yang diwawancarai dalam suasana santai, kurang formal dan tidak disediakan jawaban oleh pewawancara. Wawancara ini dimaksudkan untuk memperoleh informasi mengenai adat tradisi bertandang di Desa Tunggul Bulin.

\section{Dokumentasi}

\footnotetext{
${ }^{1}$ Wawancara dan Observasi, Desember 2017
} 
Dokumentasi dari asal katanya dokumen, yang artinya barang-barang tertulis. Di dalam melaksanakan metode dokumentasi, peneliti menyelidiki benda-benda tertulis seperti buku-buku, majalah, dokumen, peraturan-peraturan, catatan harian, dan sebagainya (Arikunto, 2006).

Peneliti melakukan dokumentasi pelaksanaan kegiatan penelitian melalui foto atau gambar, sebagai bukti fisik pelaksanaan penelitian. Serta profil Desa Tunggul Bulin.

\section{Jenis Data}

Sumber data yang digunakan peneliti adalah:

\section{Data Primer}

Data primer adalah data yang diperoleh langsung dari informan. Yang termasuk data primer adalah transkrip hasil wawancara mengenai penggunaan facebook sebagai model bertandang baru di era digital.

\section{Data Sekunder}

Data sekunder yaitu data yang diperoleh secara tidak langsung dari objek penelitian. Pengumpulan data sekunder dalam penelitian ini dengan cara penelitian kepustakaan dan pencatatan dokumen, yaitu dengan mengumpulkan data dan mengambil informasi dari buku-buku referensi, dokumen, foto, majalah, jurnal, artikel dan internet yang dianggap relevan dengan masalah yang diteliti.

\section{Teknik Penentuan Informan}

Pada penelitian kualitatif tidak menggunakan istilah populasi yang ada adalah istilah kata informan yang nantinya akan diwawancarai secara mendalam yang berkaitan dengan permasalahan yang akan diteliti dan dibahas dalam penelitian ini. Informan pada penelitian kualitatif ini dipilih dan ditentukan dengan pertimbangan-pertimbangan tertentu yang telah ditentukan oleh peneliti.

Teknik pemilihan informan yang digunakan oleh peneliti dalam penelitian ini adalah dengan menggunakan metode purposive sampling (teknik penentuan sampel dengan pertimbangan tertentu) karena dalam teknik proporsive sampling ini sudah ditetapkan terlebih dahulu siapa saja yang akan dijadikan informan dalam penelitian ini yaitu dilakukannya dengan cara mengambil subjek bukan berdasarkan atas strata random atau daerah tetapi berdasarkan atas adanya tujuan tertentu dan dilakukannya karena beberapa pertimbangan diantaranya adalah populasi yang dipilih untuk dijadikan sampel dapat dipilih sedemikian rupa menurut kriteria-kriteria yang telah ditentukan sehingga akan relevan dengan rencana penelitian (Sugiyono, 2013). Tabel 2 merupakan daftar calon informan:

Tabel 2. Daftar Informan

\begin{tabular}{cllc}
\hline No. & \multicolumn{1}{c}{ Nama } & Jabatan & Jumlah \\
\hline 1. & Laduni & Kepala Desa & 1 \\
2. & Zainubi & Tokoh Adat & 1 \\
3. & Tobroni & Tokoh Pemuda & 1 \\
4. & Rozali & Tokoh Pemuda & 1 \\
5. & Najmi Laila & Tokoh Pemudi & 1 \\
6. & Rendi Astika & Tokoh Pemudi & 1 \\
7. & Saihu & Tokoh Masyarakat & 1 \\
& Total & & 7 \\
\hline
\end{tabular}

\section{Analisis Data}

Analisis data dalam penelitian ini dilakukan secara induktif, yaitu analisa yang dimulai dari pengumpulan data, reduksi data, penyajian data, dan verifikasi data.

Data-data yang diperoleh dari lapangan akan diatur, diurutkan, dikelompokkan ke dalam kategori, pola atau uraian tertentu. Analisis data dimulai dengan menelaah seluruh data yang tersedia dari berbagai sumber, yaitu pengamatan dan wawancara mendalam, yang sudah dituliskan dalam catatan lapangan. Dalam proses analisis data dimulai dengan menelaah seluruh data yang diperoleh dari berbagai sumber antara lain dari wawancara, pengamatan lapangan yang sudah ditulis dalam cacatan lapangan, serta dokumen yang telah diperoleh. Kemudian diseleksi, ditelaah serta dikaji lalu 
diabstraksikan. Abstraksi yang dimaksud adalah usaha membuat rangkuman inti proses dan pernyataan-pernyataan yang perlu dijaga sehingga tetap dalam koridor penelitian (Sugiyono, 2013).

Setelah data terkumpul, disusun dalam lembar-lembar rangkuman, selanjutnya peneliti mengidentifikasi data yang ada untuk masing-masing pokok permasalahan dalam lembar tersendiri. Hal ini dimaksudkan agar peneliti lebih mudah melakukan pengecekan terhadap setiap data yang ada. Pengecekan ini dilakukan karena tidak semua informan sama dalam memberikan jawaban terhadap suatu permasalahan, untuk lebih memantapkan kesimpulan yang akan diambil peneliti. Bila dirasa ada kekurangan dalam reduksi data maupun sajian data maka dilakukan penggalian data kembali dalam cacatan lapangan dan terjun kembali ke lapangan. Setelah data yang diharapkan terkumpul semua, barulah menarik kesimpulan untuk setiap pokok permasalahan yang ada (Sugiyono, 2013).

\section{HASIL DAN PEMBAHASAN}

\section{Penggunaan facebook sebagai Model Tradisi Bertandang Baru di era digital di Desa Tunggul Bulin Kecamatan Tabir Ilir Kabupaten Merangin}

Meskipun berpredikat sebagai orang-orang Islam, tetapi masyarakat Desa Tunggul Bulin tetap menjunjung tinggi adat istiadat yang memang telah mendarah daging dalam kehidupan sehari-hari mereka. Kondisi seperti ini tampak mengemuka dengan adanya adagium yang sangat terkenal dalam masyarakat desa ini, yaitu adat bersendi syara', syara' bersendi kitabullah. Adagium ini berarti bahwa segala aspek kehidupan sehari-hari masyarakat diatur oleh adat yang diwarisi dari nenek moyang mereka, di mana adat tersebut dibuat berdasarkan ajaran Islam yang mereka anut.

Secara resmi masyarakat Desa Tunggul Bulin, bahkan Provinsi Jambi pada umumnya, tidak mengenal adanya strata atau sturuktur sosial yang membedakan antara satu individu dengan individu lainnya. Meskipun demikian, dalam kehidupan sehari-hari struktur sosial tersebut terlihat dan mengemuka dalam masyarakat. Berdasarkan pengamatan dan pemahaman peneliti di lapangan, struktur sosial yang berlaku dalam masyarakat desa ini terdiri dari empat bagian, yaitu: ulama, pemangku, rakyat biasa dan pendatang.

Golongan ulama adalah orang-orang yang merupakan ahli agama yang memang telah dikenal dalam masyarakat sejak dahulu kala. Golongan ini rata-rata bergelar haji atau memiliki pengetahuan agama yang lebih baik dibandingkan masyarakat kebanyakan yang ada di desa ini. Kelompok ini memegang jabatan imam masjid, guru mengaji dan beragam jabatan yang berkaitan dengan keagamaan yang ada di desa ini. Sedangkan kelompok pemangku adalah orang-orang yang memegang jabatan struktural atau pemerintahan di Desa Tunggul Bulin, baik kepala desa; kepala dusun; ketua RT dan lain sebagainya. Kedua kelompok yang dianggap keturunan pendiri desa ini merupakan orang-orang terpandang dan memiliki kekayaan melebihi apa yang dimiliki oleh kelompok lainnya. Adapun orang biasa adalah masyarakat desa yang bukan termasuk dua kelompok sebelumnya, tetapi merupakan penduduk asli desa ini sedangkan pendatang adalah orang-orang yang datang dari luar desa yang kemudian menetap karena berbagai keperluan, bekerja sebagai penyadap karet misalnya.

Dua golongan yang disebutkan pertama merupakan kalangan terpandang dalam masyarakat karena merekalah penggerak pemerintahan dan segala sistem yang berlaku di desa ini. Segala titah dan perintah yang biasanya mewujud dalam aturan dan adat desa menjadi tuntunan masyarakat dalam kehidupan sehari-hari. Dalam konteks pengelolaan perkebunan karet rakyat di desa ini, kedua kelompok ini memainkan peranan yang signifikan karena mereka memiliki mayoritas perkebunan karet yang ada di desa ini. Dengan posisinya sebagai kalangan 'darah biru' dalam masyarakat ditambah lagi dengan faktor ekonomi yang di atas masyarakat kebanyakan, maka kelompok ulama dan pemangku berperan layaknya tuan kepada para pengikutnya. Masing-masing orang dalam kedua kelompok ini memiliki bawahan yang berposisi layaknya 'anak buah', baik perannya sebagai kalangan ningrat desa maupun dalam pengelolaan perkebunan karet. Para bawahan yang bekerja dengan mereka tersebut melaksanakan segala titah yang diperintahkan oleh kedua kalangan ningrat tersebut.

Peranan vital yang dimainkan oleh kedua kelompok 'darah biru' ini memungkinkan dapat terjadi di samping karena faktor ekonomi yang mereka miliki, juga yang terpenting adalah budaya setempat yang menempatkan mereka dalam posisi teratas. Menurut budaya yang berlaku dan diyakini oleh masyarakat desa ini, kedua kalangan ini adalah keturunan langsung para pemuka atau para pendiri desa ini dahulu kala. Dengan demikian, segala hal yang berkaitan dengan desa ini dimainkan 
secara signifikan oleh kedua kalangan ini, sedangkan dua golongan lainnya sebagai pengikut atau pihak yang menjalankan dan tunduk pada kedua golongan di atas mereka.

Di Desa Tunggul Bulin terdapat adat istiadat yang sudah mulai pudar yakni adat tradisi bertandang, bertandang adalah pergi ke rumah seseorang untuk melakukan silaturrahmi, berdiskusi, bertanya, dan mendapatkan suatu informasi. Istilah bertandang sangat dikenal dalam masyarakat Melayu yang berdiam di Kecamatan dalam Marga Tabir Kabupaten Merangin.

Kemajuan dan modernisasi sangat banyak mempengaruhi tradisi dan budaya manusia, seperti tradisi bertandang budaya anak muda yang sudah menghilang, bertandang bukan perempuan dan laki berpacaran seperti ditempat gelap akan tetapi mereka memiliki tata krama untuk melakukan pendekatan yang ditemani oleh orang tua pihak perempuan. Demikian juga tradisi bertandang adalah tradisi anak muda zaman dahulu, cara-cara mereka untuk melakukan penjejakan dan berkenalan melalui aturan-aturan adat di Desa Tunggul Bulin.

Bertandang adalah pendekatan seorang laki (perjaka) terhadap seorang perempuan (perawan) untuk melakukan pendekatan dan penjejakan. Waktu bertandang dilakukan pada malam hari setelah shalat Isa dan makan malam (biasa sekitar pukul 20.00 s.d 22.00), sebelum seorang laki-laki bertandang akan diberikan informasi melalui perantara oleh orang terdekat bahwa ada seseorang yang akan bertandang malam nanti ke rumah ini.

Pihak perempuan akan memberitahukan kepada perantara bahwa ia bersedia menerima atau tidak, setelah terjadi kesepakatan pertandangan akan dilaksanakan oleh seorang laki-laki, kadangkadang jika laki-laki yang bersangkutan merasa canggung dan kaku, ia akan membawa seseorang teman sebagai pedamping atau juru bicara, demikian pula pihak perempuan seorang anak gadis tidak dibiarkan sendirian akan tetapi didampingi oleh ibu atau neneknya. Adat melarang acara bertandang berdua-duaan di rumah, jika pertandangan kedepatan berduaan oleh masyarakat, maka mereka akan dikenakan denda adat (kambing satu, beras sepuluh gantang) pertandangan memiliki aturan tidak tertulis, duduknya seorang laki-laki yang bertandang harus dekat pintu masuk ke rumah dan tidak boleh masuk jauh ke dalam rumah.

Tempo dulu rumah di Desa Tunggul Bulin adalah rumah panggung dengan penerang lampu taplok (lampu sumbu). Bertandang disamping silaturrahmi, pendekatan, dan hiburan, antara laki-laki dan pihak perempuan saling berpantun dan menjawab pantun menunjukkan isi hati mereka, biasanya mereka mempergunakan kata-kata kiasan dan bermakna. Tatkala sudah merasa satu perasaan, pertandangan akan bisa dilanjutkan pada malam-malam berikutnya tanpa perantara, cukup pihak lakilaki buatkan tanda siulan dan batuk di samping rumah, maka pihak perempuan mempersilakan naik ke rumah. Mereka yang telah menjalin cinta dan kasih sayang menandainya dengan tukar menukar tanda mata, seperti sapu tangan, kain panjang, kain sarung, cincin, dan tanda mata lainnya.

Pertandangan merupakan cikal bakal untuk merajut rumah tangga, manakala seorang laki-laki dan seorang perempuan telah sepakat bahwa mereka melanjutkan ke jenjang rumah tangga, dia (perempuan) melaporkan kehadapan orang tuanya bahwa dia akan dipinang oleh pihak laki-laki oleh mamak (paman) nenek yang empat dan puyang yang delapan datang ke rumah pihak perempuan, pihak perempuan juga menyiapkan penyambutnya dengan nenek yang empat dan puyang delapan. Mereka (pihak laki-laki) melamar dan jika lamaran itu diterima biasanya diteruskan pada penentuan hari menikah dan walimatul urushnya serta penentua mahar perempuan.

Tradisi bertandang lambat laun memudar dan menghilang seiring dengan perkembangan pengetahuan, teknologi, seni, dan budaya di tengah masyarakat, pendidikan yang tinggi di tengah masyarakat yang membuat tradisi bertandang tidak lagi dilakukan, mereka sudah berkirim pesan, bertemu di sekolah, di jalan, di pasar, dan di berbagai tempat. Kemudian juga teknologi seperti media, penerang listrik, dan informasi juga membuatkan tradisi bertandang memudar dan menghilang, salah satu penyebab terbesarnya adalah penggunaan media sosial, khususnya facebook. Hal ini dapat dijelaskan sebagai berikut:

\section{Penggunaan Facebook dalam mencari teman}

Jika pada masa dahulu pemuda dan pemudi di Desa Tunggul Bulin mencari teman atau perkenalan melalui kegiatan adat seperti ke Talang Petang, penggunaan istilan ke Talang Petang dikarenakan pada sore hari sebelum pelaksanaan gotong royong menanam padi tersebut para mudamudi berangkat ke Talang, Talang menunjukan lokasi kebun yang akan ditanami padi yang sangat jauh dari desa, ke Talang Patang yaitu acara menanam padi yang dilakukan secara gotong royong 
Jurnal Politik dan Pemerintah Daerah, 1 (2), 2019 - 101

Andika Andika, Mulia Jaya

dengan dibantu muda-mudi, dimana di acara tersebut biasanya yang muda dan mudi saling mencuri waktu untuk sekedar mengobrol saling kenal mengenal antara satu dengan yang lainnya. Hal ini sebagaimana disampaikan oleh Bapak Zainubi selaku Tokoh adat Desa Tunggul Bulin, berikut penuturannya:

“...dulu muda mudi berkenalan saat ada acara adat, seperti pergi ke Talang Petang, mereka saling berkenalan saat kegiatan gotong royong berlangsung, biasanya para lelaki yang menunggalkan padi (membuat lubang) sedangkan perempuan yang memasukan benih, pada saat itulah terjadi komunikasi antara lekaki dan perempuan..."

Hal ini menunjukan bahwa adat bertandang lebih menekankan interaksi sosial, Mar'at menegaskan bahwa interaksi sosial merupakan suatu proses di mana individu memperhatikan, merespon terhadap individu lain, sehingga direspon dengan suatu tingkah laku tertentu (Mar'at, 2008). Dalam kehidupan bermasyarakat interaksi sosial merupakan bagian dari proses sosial. Interaksi sosial juga mempengaruhi perilaku seseorang, dimana perilaku digerakkan atau dimotivasi untuk memperoleh kesenangan. Selanjutnya beliau menambahkan:

“...sekarang kondisinya tidak seperti itu lagi, sejak adanya HP sekarang sudah banyak muda-mudi berkenalan melalui HP, jarang sekali mereka berkenalan di acara tersebut, apalagi bertandang. Dengan HP mereka sudah bisa berkenalan dengan cewek atau cowok di luar Desa Tunggul Bulin ini"”3

Jika dikaitkan dengan penggunaan media sosial sebagai model bertandang baru, maka memudahkan kaum muda-mudi untuk berinteraksi dengan banyak orang. Facebook memungkinkan mereka untuk berinteraksi dengan temannya (calon pasangannya). Mereka pun dapat mengetahui kehidupan dan kegiatan sehari-hari mereka dari akun mereka. Tidak sebatas itu saja, penggunaan Facebook mampu menutupi perasaan malu saat mereka bertandang secara langsung. apalagi ketika harus berkenalan langsung dengan seorang wanita. maka media sosial merupakan solusi. Mereka tidak lagi harus menghadapi ketegangan, kegugupan, dan gemetar ketika mereka mendekati seorang wanita.

Pendapat yang sama juga disampaikan oleh Ahmad Rozali tokoh Pemuda Desa Tunggul Bulin, berikut penjelasannya:

“...kalau dulu anak muda berkenalan saat ada acara adat, seperti bantaian adat, ke talang petang, menuai padi, acara berelek, namun sekarang semenjak adanya HP serta adanya facebook maka perkenalan tidak mengandalkan acara adat lagi, orang-orang sudah menggunakan facebook untuk mencari teman" $" 4$

Pernyataan tersebut menggambarkan bahwa facebook telah banyak digunakan oleh anak muda di Desa Tunggul Bulin dan telah menjadi sarana perkenalan muda-mudi, hal ini tidak terlepas dari kemudahan yang diberikan oleh layanan facebook dalam berkomunikasi, di mana selain dapat melihat tampilan gambar dan video facebook juga telah menambahkan fitur penggilan video (video call) pada aplikasi tersebut, tentulah hal tersebut membuat pengguna mendapatkan pengalaman lebih dalam berkomunikasi.

Kondisi ini juga dirasakan oleh Najmi Laila selaku masyarakat di Desa Tunggul Bulin, berikut penuturannya:

“...kami merasakan banyak perubahan karena adanya facebook, sekarang banyak orang yang menikah dengan orang sini berasal dari jauh, ada yang kenalan di Facebook dengan orang Palembang lalu menikah, kalau dulu orang banyak berkenalan dengan orang dusun sini lah, paling jauh ya dusun tetangga"

Telepon seluler pada saat ini tidak hanya digunakan oleh kalangan dewasa dan orang tua saja. Anak muda pun sudah banyak yang menggunakan telepon seluler dengan kecanggihan yang tidak kalah dengan telepon seluler orang dewasa. Pada anak muda selain sebagai alat komunikasi, telepon

\footnotetext{
${ }^{2}$ Wawancara dengan Bapak Zainubi selaku Tokoh adat Desa Tunggul Bulin, tanggal 19 April 2018

${ }^{3}$ Wawancara dengan Bapak Zainubi selaku Tokoh adat Desa Tunggul Bulin, tanggal 19 April 2018

${ }^{4}$ Wawancara dengan Ahmad Rozali, tokoh Pemuda Desa Tunggul Bulin, tanggal 21 April 2018

${ }^{5}$ Wawancara dengan Najmi Laila selaku Tokoh Pemudi Desa Tunggul Bulin, tanggal 21 April 2018
} 
seluler bertambah fungsinya sebagai pelengkap gaya hidup. Mereka menggunakan ponsel yang memiliki aplikasi facebook karena sudah menjadi kebutuhan dan kesenangan bagi mereka, dengan ponsel tersebut mereka bisa berbagi dengan orang lain. Mereka juga mengisi waktu kosong dengan bermain facebook melalui ponsel. Dengan itu mereka menjadikannya suatu hiburan dan kesenangan mereka. Selain itu juga, ponsel yang memiliki aplikasi facebook sangat praktis, bisa dibawa kemanamana jadi mereka dapat mengaksesnya kapan saja mereka mau.

Kedua aplikasi ini sangat populer dan merupakan tempat mereka berkomunikasi dengan orang lain melalui jalur dunia maya. Dengan aplikasi-aplikasi tersebut, masyarakat dapat berinteraksi baik dengan orang yang sudah sangat dikenalnya maupun dengan yang baru dikenal, dengan tidak lagi memikirkan jarak sebagai hambatan komunikasi. Selain situs facebook, dengan ponsel pengguna juga mendapat banyak informasi dari layanan internet tersebut. Tidak perlu lagi menggunakan komputer yang harus duduk di depannya atau laptop yang harus menggunakan modem atau harus berada di tempat yang memfasilitasi layanan internet. Dengan telepon genggam yang bisa dibawa ke manamana dan kapan saja, masyarakat jadi lebih mudah mengaksesnya.

\section{Mengenal dari Profil Facebook}

Jika dalam adat bertandang untuk mengenal seseorang, maka diharuskan bertemu atau bertanya dengan orang lain, sementara dengan penggunaan media sosial facebook seseorang cukup melihat profil dalam aplikasi tersebut, meskipun kebenaran data dalam profil tersebut masih diragukan, hal ini sebagaimana disampaikan Ahmad Rozali selaku tokoh Pemuda Desa Tunggul Bulin, berikut penuturannya:

“...bertandang itu kan intinya adalah media untuk perkenalan, dengan bertandang orang jadi tahu siapa kenalannya, mereka dapat mengenal lebih dekat antara satu dengan yang lainnya, sementara dengan adanya facebook seseorang yang ingin mengenal yang lain cukup dengan melihat profil di facebook orang tersebut, meskipun yang ada di profil tersebut belum tentu benar..." 6

Jika dikaitkan dengan penggunaan media sosial sebagai model bertandang baru, maka penggunaan facebook mengurangi bentuk tatap muka dalam interaksi sosial pada tradisi bertandang. Meski pun Facebook telah mampu menggunakan video call dalam komunikasinya namun belum mampu menggantikan keberadaan seseorang dalam berinterkasi secara lansung.

Selanjutnya beliau menambahkan:

“....untuk bisa bertandang ke rumah gadis yang ingin dikenal belum tentu diizinkan main ke rumahnya, sedangkan dengan facebook orang dapat melihat profil siapapun tanpa harus mendapat izin, itu yang membuat muda-mudi sekarang mulai meninggalkan adat tradisi bertandang di Desa Tunggul Bulin ini..."

Pernyataan tersebut juga dibenarkan oleh Najmi Laila saat wawancara, berikut pernyataannya:

“...beda dengan bertandang, kalau bertandang harus ada kata sepakat, baik waktu pelaksanaannya, izin dari orang tuanya, atau izin dari wanita itu sendiri, sementara kalau menggunakan facebook orang tidak perlu izin dari orang tua tersebut untuk mengenal dan menjalin komunikasi, cukup melalui facebook aja, pengenalan awal pun dapat dengan melihat profilnya, jika pada tradisi bertandang itu pihak laki-laki yang bertandang kepada pihak perempuan, maka di media sosial facebook bisa saja wanita yang mengajak berteman, sehingga ini mendorong muda-mudi di Desa Tunggul Bulin meningalkan tradisi bertandang dan beralih pada penggunaan facebook. ${ }^{8}$

Jejaring sosial semisal facebook merupakan sarana berinteraksi secara virtual dengan orangorang yang ada di seantero dunia. Bagi pengguna yang bisa memamfaatkan media sosial ini dengan baik, maka yang bersangkutan akan memetik banyak manfaat semisal mendapatkan account teman lama, mendapatkan berbagai jenis informasi yang aktual di tengah masyarakat ataukah mencari jejaring/ teman baru. Ada pula sebagian masyarakat yang memanfatkan dan mencoba peruntungan untuk mencari jodoh lewat jejaring sosial ini. Ada yang beruntung namun ada juga yang bernasib sial.

\footnotetext{
${ }^{6}$ Wawancara dengan Ahmad Rozali, tokoh Pemuda Desa Tunggul Bulin, tanggal 21 April 2018

${ }^{7}$ Wawancara dengan Ahmad Rozali, tokoh Pemuda Desa Tunggul Bulin, tanggal 21 April 2018

${ }^{8}$ Wawancara dengan Najmi Laila selaku Tokoh Pemudi Desa Tunggul Bulin, tanggal 21 April 2018
} 
Facebook merupakan salah satu situs jejaring sosial yang sebagian besar penggunanya memanfaatkan untuk pertemanan. Begitu juga dengan pengguna di Desa Tunggul Bulin. Rata-rata responden menggunakan Facebook untuk hal pertemanan, informan berpendapat bahwa hal yang paling sering dilihat dari profil temannya adalah galeri foto, tampilan profil, dan identitas pribadi teman. Hal ini terjadi karena biasanya, dengan melihat ketiga aspek penggunaan tersebut informan dapat lebih mengenal temannya. informan dapat melihat pribadi temannya dari foto yang di-upload, tampilan profilnya dan identitas pribadinya. Hal ini sebagaimana disampaikan oleh Tobroni selaku tokoh pemuda Desa Tunggul Bulin, berikut keterangannya:

“...dengan melihat foto-foto atau galeri foto teman, seseorang dapat merasa terhibur. Selain itu, apabila membuka identitas atau membaca profil seorang teman, seseorang akan dapat merasa lebih gembira melihat orang yang dikenalnya berada di jejaring sosial, seorang lelaki juga bisa mengenali wanita dari profil yang dibuatnya, foto yang diuploadnya, karena itu mencermin siapa dia sebenarnya... ${ }^{9}$

Hal ini seperti juga diungkapkan oleh Rendi Astika sebagai berikut:

“....Saya senang saja kalo melihat galeri foto temen-temen saya. Karena dari situ kita bisa melihat siapa dia, apa yang dimilikinya, karena terkadang orangkan suka pamer, jadi menampilkan di facebook." 10

\section{Komunikasi Tanpa Rasa Gugup}

Saat pelaksanaan bertandang, tidak semua orang mempunyai kemampuan komunikasi secara verbal, karena adanya perasaan gugup, apalagi pada tradisi bertandang sering menggunakan bahasa pantun yang dilakukan secara berbalas, namun dengan penggunaan media sosial facebook perasaan gugup tersebut dapat dihilangkan karena komunikasi dilakukan secara tidak langsung atau melalui perantara media, sehingga raut wajah tidak terlihat, hal ini sebagaimana disampaikan oleh Ahmad Rozali, tokoh Pemuda Desa Tunggul Bulin, berikut penjelasannya:

“....mengapa orang lebih suka menggunakan facebook daripada bertandang, salah satunya adalah kemampuan berkomunikasi, jika dalam bertandang orang menggunakan bahasa pantun dan sindiran, sementara dalam penggunaan media sosial hanya menggunakan bahasa sehari-hari, kemudian pada saat bertandang orang-orang berhadapan langsung, ketika berkomunikasi secara langsung tentunya dibutuhkan keberanian yang tinggi, tidak gugup, beda dengan menggunakan facebook, orang hanya mengetik, sementara wajah tidak terlihat, jadi rasa gugup itu tidak ada..."11

Kenyataan tersebut juga dibenarkan oleh Najmi Laila selaku pemudi Desa Tunggul Bulin, berikut pernyataannya:

“....kelebihan penggunaan facebook dalam bertandang diera digital ini adalah tidak adanya perlakukan berbeda antara laki-laki dan perempuan dalam berkomunikasi, jika mengikuti bertandang pada zaman dahulu, pihak perempuan hanya bersifat pasif, jika ditanya barulah menjawab, berbeda sekali dengan penggunaan media sosial seprti facebook, antara laki-laki dan perempuan tidak ada batasan dalam berkomunikasi, silakan saja siapa yang memulai duluan, dan tidak ada rasa canggung atau gugup bagi perempaun untuk mengajukan pertanyaan atau mengungkap isi hatinya..."12

Jika dikaitkan dengan penggunaan media sosial sebagai model bertandang baru, maka memudahkan kaum muda-mudi untuk berinteraksi dengan banyak orang. Facebook memungkinkan mereka untuk berinteraksi dengan temannya (calon pasangannya). Mereka pun dapat mengetahui kehidupan dan kegiatan sehari-hari mereka dari akun mereka. Tidak sebatas itu saja, penggunaan Facebook mampu menutupi perasaan malu saat mereka bertandang secara langsung. apalagi ketika harus berkenalan langsung dengan seorang wanita. maka media sosial merupakan solusi. Mereka tidak lagi harus menghadapi ketegangan, kegugupan, dan gemetar ketika mereka mendekati seorang wanita.

\footnotetext{
${ }^{9}$ Wawancara dengan Tobroni, tokoh Pemuda Desa Tunggul Bulin, tanggal 23 April 2018

${ }^{10}$ Wawancara dengan Rendi Astika selaku Muda-mudi Desa Tunggul Bulin, tanggal 21 April 2018

${ }^{11}$ Wawancara dengan Ahmad Rozali, tokoh Pemuda Desa Tunggul Bulin, tanggal 21 April 2018

${ }^{12}$ Wawancara dengan Najmi Laila selaku Tokoh Pemudi Desa Tunggul Bulin, tanggal 21 April 2018
} 
“....mengapa orang lebih suka menggunakan facebook daripada bertandang, salah satunya adalah kemampuan berkomunikasi, jika dalam bertandang orang menggunakan bahasa pantun dan sindiran, sementara dalam penggunaan media sosial hanya menggunakan bahasa sehari-hari, kemudian pada saat bertandang orang-orang berhadapan langsung, ketika berkomunikasi secara langsung tentunya dibutuhkan keberanian yang tinggi, tidak gugup, beda dengan menggunakan facebook, orang hanya mengetik, sementara wajah tidak terlihat, jadi rasa gugup itu tidak ada..."13

Informan menyatakan bahwa dengan adanya kemudahan ini, interkasi dengan teman yang berjauhan dapat dilakukan dengan mudah tanpa harus bertatap muka secara langsung. Facebook dapat menjadi alternatif komunikasi yang digemari banyak orang. Terlebih lagi bagi orang yang memiliki kepribadian tertutup, pemalu, ataupun pendiam. Berkomunikasi melalui Facebook, tidak perlu memperlihatkan diri secara fisik, misalnya saling bertatap muka.

Antara perseorangan dan kelompok, dan antara kelompok dan kelompok. Interaksi sosial dapat berlaku apabila antara dua individu atau kelompok terdapat kontak sosial dan komunikasi. Kontak sosial merupakan tahap pertama dari terjadinya hubungan sosial. Komunikasi merupakan penyampaian suatu informasi dan pemberian tafsiran dan reaksi terhadap informasi yang disampaikan.

\section{Faktor yang mempengaruhi penggunaan facebook sebagai Model Tradisi Bertandang di Era Digital}

Berdasarkan wawancara dengan beberapa informan di Desa Tunggul Bulin diketahui bahwa banyak faktor yang mempengaruhi penggunaan facebook sebagai model tradisi bertandang di era digital dan memudarnya tradisi bertandang di Desa Tunggul Bulin, diantaranya adalah:

\section{Menjamurnya penggunaan HP}

Menjamurnya penggunaan handphone (HP) dikalangan masyarakat desa Tunggul Bulin menjadi faktor pendorong bagi penggunaan facebook sebagai model tradisi bertandang di era digital dan memudarnya tradisi bertandang di Desa Tunggul Bulin, dimana dahulu sinyal menjadi kendala namun semenjak masuknya jaringan komunikasi dengan dibangunnya beberapa tower (BTS) di beberapa desa sekitaran Desa Tunggul Bulin beberapa tahun terakhir membuat masyarakat sangat antusias membeli HP sebagai alat komunikasi, hal inilah yang mendorong pertumbuhan penggunaan facebook di Desa Tunggul Bulin meningkatkan, sebagaimana disampaikan oleh Bapak Laduni selaku Kepala Desa Tunggul Bulin, berikut penjelasannya:

“.....dulu sinyal susah di Desa Tunggul Bulin ini, semenjak ada beberapa provider yang membangun tower di dekat Desa Tunggul Bulin maka banyak masyarakat yang membeli HP untuk komunikasi, seiring perkembangan zaman, maka HP bukan hanya sekedar untuk komunikasi telpon maupun sms saja, namun sudah mampu menggunakan media sosial salah satunya adalah facebook,.. ${ }^{14}$

Selanjutnya beliau menambahkan:

“....dengan menjamurnya penggunaan HP tersebut maka banyak muda-mudi yang berkomunikasi dengan HP, ditambah lagi dengan perkembangan media sosial seperti facebook maka tradisi bertandang semakin lama semakin ditinggalakan.

Pernyataan tersebut dibenarkan oleh Bapak Saihu selaku tokoh adat Desa Tunggul Bulin, berikut kutipan wawancaranya:

“...semenjak harga HP mulai terjangkau bagi masyarakat, maka banyak orang tua yang membelikan HP untuk anak mereka, hadirnya media sosial seperti facebook mendorong muda-mudi untuk meninggalkan kebiasaan lama dalam pergaulan, yang biasanya dilakukan secara bertandang namun sekarang cukup menggunakan facebook saja, faktor ini yang mendorong orang menggunakan facebook sebagai sarana bertandang di Desa Tunggul Bulin... "15

\footnotetext{
${ }^{13}$ Wawancara dengan Ahmad Rozali, tokoh Pemuda Desa Tunggul Bulin, tanggal 21 April 2018

${ }^{14}$ Wawancara dengan Bapak Laduni selaku Kepala Desa Tunggul Bulin,, tanggal 19 April 2018

${ }^{15}$ Wawancara dengan Bapak Saihu selaku tokoh adat Desa Tunggul Bulin, tanggal 20 April 2018
} 
Facebook merupakan salah satu situs jejaring sosial yang menyediakan wadah untuk para pengguna agar dapat melakukan interaksi secara mudah dan murah. Pada umumnya pengguna Facebook di Desa Tunggul Bulin memanfaatkan jejaring sosial ini untuk berinteraksi dengan pengguna lainnya. Biasanya, muda-mudi melakukan interaksi dengan menggunakan kemudahan atau aplikasi chatbox yang telah disediakan oleh Facebook.

Sehingga tidak heran bila ada suatu komunitas masyarakat yang kurang siap menghadapi perkembangan tersebut dan mengakibatkan terjadinya krisis nilai dan norma didalam masyarakat. Sebenaranya media sosial tidak hanya mempunyai dampak negatif tetapi juga banyak terdapat dampak positifnya. Media sosial memberikan manfaat yang begitu besar tetapi di lain pihak media sosial menjadi suatu media informasi yang tidak mudah dibatasi, berbagai macam informasi dalam berbagai bentuk dan tujuan bercampur menjadi satu di mana untuk mengaksesnya hanya perlu satu sentuhan jari saja.

Penggunaan Facebook Tanpa batasan waktu dan ruang

Berdasarkan wawancara dengan beberapa infroman diketahui bahwa faktor lain yang mempengaruhi penggunaan facebook sebagai model tradisi bertandang di era digital adalah tidak adanya batasan ruang dan waktu jika berkomunikasi melalui media sosial seperti facebook, hal ini sebagaimana disampaikan oleh Bapak Laduni selaku Kepala Desa Tunggul Bulin, berikut penjelasannya:

“....menurut saya faktor yang membuat facebook menggantikan tradisi bertandang di Desa Tunggul Bulin adalah kelebihan yang dimiliki oleh media sosial yang berbasis jaringan atau internet, karena internet tersebut tidak mengenal batas ruang dan waktu, melalui facebook pemuda Desa Tunggul Bulin dapat berkenalan dengan Pemudi Ulak Makam atau pemudi di Desa Rantau Limau Manis, tanpa harus pergi ke desa tersebut...."

Selanjutnya beliau menambahkan:

“....melalui facebook juga tidak harus bertandang di malam hari, kapanpun bisa dan dimana pun, sehingga kemudahan-mudahan tersebut mampu menggeserkan adat tradisi bertandang sebagai sarana atau wadah perkenalan muda-mudi di Desa Tunggul Bulin.. ",17

Pernyataan yang sama juga disampaikan oleh Ahmad Rozali, tokoh Pemuda Desa Tunggul Bulin, berikut penuturannya:

“....menurut saya yang membuat muda-mudi lebih memilih facebook ketimbang harus bertandang adalah kemudahan yang diberikan facebook, dimana berkomunikasi melalui facebook muda-mudi tidak mengenal adanya jarak dan waktu sebagai pengalang, muda-mudi dapat berkenalan dengan siapapun dan dimanapun tanpa harus takut terhalang jarak yang jauh..."

Proses interaksi sosial disosiatif adalah proses oposisi (oppositional process) yang berarti berjuang melawan seorang ataupun sekelompok orang untuk meraih tujuan tertentu. Interaksi disosiatif dibedakan menjadi beberapa bentuk antara lain persaingan (competition), kontravensi atau sikap menentang dengan tersembunyi, pertikaian sebagai lanjutan dari kontravensi, dan pertikaian atau konflik.

Kondisi tersebut dibenarkan oleh Najmi Laila selaku pemudi Desa Tunggul Bulin, berikut kutipannya:

“...kelebihan facebook dibanding bertandang itu adalah kebebesan waktu dan jarak, maka banyak sekali muda-mudi di Desa Tunggul Bulin yang dinikah dengan orang luar maupun sebaliknya hanya menggunakan perkenalan melalui facebook.." "I8

Informan menyatakan bahwa dengan adanya kemudahan ini, interkasi dengan teman yang berjauhan dapat dilakukan dengan mudah tanpa harus bertatap muka secara langsung. Facebook dapat menjadi alternatif komunikasi yang digemari banyak orang. Terlebih lagi bagi orang yang memiliki

\footnotetext{
${ }^{16}$ Wawancara dengan Bapak Laduni selaku Kepala Desa Tunggul Bulin,, tanggal 19 April 2018

${ }^{17}$ Wawancara dengan Bapak Laduni selaku Kepala Desa Tunggul Bulin,, tanggal 19 April 2018

${ }^{18}$ Wawancara dengan Najmi Laila selaku Tokoh Pemudi Desa Tunggul Bulin, tanggal 21 April 2018
} 
kepribadian tertutup, pemalu, ataupun pendiam. Berkomunikasi melalui Facebook, tidak perlu memperlihatkan diri secara fisik, misalnya saling bertatap muka. Internet digunakan oleh masyarakat untuk saling berinteraksi satu dengan yang lain tanpa adanya batasan waktu dan wilayah. Hal ini sangat membantu masyarakat itu sendiri. Mengingat kondisi masyarakat sekarang ini yang tidak lagi mempunyai waktu luang untuk berkumpul atau bertemu secara langsung yang disebabkan oleh tingkat kompleksitas hidup masyarakatnya yang sangat tinggi. Oleh karena itu, internet dijadikan sebagai salah satu kebutuhan bagi masyarakat modern dalam proses interaksinya.

\section{SIMPULAN}

Tradisi bertandang lambat laun memudar dan menghilang seiring dengan perkembangan pengetahuan, teknologi, seni, dan budaya di tengah masyarakat, pendidikan yang tinggi di tengah masyarakat yang membuat tradisi bertandang tidak lagi dilakukan, mereka sudah berkirim pesan, bertemu di sekolah, di jalan, di pasar, dan di berbagai tempat. Kemudian juga teknologi seperti media, penerang listrik, dan informasi juga membuatkan tradisi bertandang memudar dan menghilang, salah satu penyebab terbesarnya adalah penggunaan media sosial, khususnya facebook. Hal ini dikarenakan penggunaan facebook dalam mencari teman, mengenal dari profil facebook, komunikasi tanpa rasa gugup.

Berdasarkan wawancara dengan beberapa informan di Desa Tunggul Bulin diketahui bahwa banyak faktor yang mempengaruhi penggunaan facebook sebagai model tradisi bertandang di era digital dan memudarnya tradisi bertandang di Desa Tunggul Bulin, diantaranya adalah: menjamurnya penggunaan HP, Penggunaan Facebook Tanpa batasan waktu dan ruang.

Diharapkan lembaga adat Desa Tunggul Bulin Kecamatan Tabir Ilir Kabupaten Merangin berupaya mempertahankan adat tradisi bertandang, dengan memberikan pembelajaran pada generasi muda, serta memberikan arahan mengenai dampak positif dan negatif dari penggunaan facebook agar dapat menjaga moral generasi muda.

\section{DAFTAR PUSTAKA}

Bogdan, R., \& Taylor, S. (1992). Pengantar metode kualitatif. Surabaya: Usaha Nasional.

Hasibuan, S. (2015). Budaya media dan partisipasi anak di era digital. In Proceedings of International Post-Graduate Conference (Vol. 1, pp. 829-850).

Mar'at. (2008). Sikap manusia perubahan serta pengukurannya. Bandung: Ghalia Indonesia

Moleong, L. J. (2004). Metodologi penelitian kualitatif. Bandung: PT Remaja Rosdakarya

Putri, W. S. R., Nurwati, N., \& Budiarti, M. (2016). Pengaruh media sosial terhadap perilaku remaja. Prosiding Penelitian dan Pengabdian kepada Masyarakat, 3(1).

Sugiyono. (2013). Metode penelitian kuantitatif, kualitatif dan R\&D. Bandung: Alfabeta.

Suharsimi, A. (2006). Prosedur penelitian suatu pendekatan praktik. Jakarta: Rineka Cipta.

Syukur, M. (1993). Buku pedoman adat Jambi. Lembaga Adat Provinsi Jambi 